\title{
PENGARUH INTELLECTUAL CAPITAL, CORPORATE GOVERNANCE DAN KARAKTERISTIK PERUSAHAAN TERHADAP KINERJA KEUANGAN PERUSAHAAN MANUFAKTUR DI INDONESIA
}

\author{
Dewa Ayu Oki Asta Rini \\ Akuntansi Universitas Bumigora Mataram \\ Oki.astarini22@gmail.com
}

\begin{abstract}
ABSTRAK
Penelitian ini bertujuan untuk menguji dan menemukan bukti empiris mengenai pengaruh intellectual capital, corporate governance dan karakteristik perusahaan terhadap kinerja keuangan pada perusahaan manufaktur dengan menggunakan alat analisis Partial Least Square. Pengujian dilakukan pada 38 perusahaan manufaktur (28,78\% dari 132 perusahaan manufaktur) dengan menggunakan data sekunder berupa laporan keuangan dan laporan tahunan dengan dari tahun 2016 sampai dengan tahun 2018. Hasil penelitan ini menunjukkan bahwa intellectual capital berpengaruh signifikan postif terhadap kinerja keuangan, yang mengindikasikan perusahaan memiliki keseriusan untuk menghasilkan nilai tambah dengan metode VAIC ${ }^{\mathrm{TM}}$ dan meningkatkan nilai intangible asset dengan metode MBIC. Karakteristik perusahaan berpengaruh signifikan positif terhadap kinerja keuangan,yang mengindikasikan semakin besarnya ukuran dan umur perusahaan akan menunjukan produktifitas perusahaan yang bagus dan adanya pengalaman manajemen untuk menghasilkan profitabilitas yang stabil. Corporate governance tidak berpengaruh signifikan terhadap kinerja keuangan, yang mengindikasikan rendahnya tingkat keselarasan pelaksanaan praktik corporate governance terhadap keseluruhan prinsip OECD (2004). Praktik corporate governance yang merujuk pada prinsip OECD (2004) masih di dominasi oleh peran stakeholder dalam corporate governance, keterbukaan dan transparansi serta tanggung jawab dewan. Kedepan perusahaan harus lebih meningkatkan perhatian dan kepatuhan terhadap prinsip hak pemegang saham dan kesetaraan perlakukan terhadap pemegang saham.
\end{abstract}

Keywords :Intellectual capital, corporate governance, karakteristik perusahaan, kinerja keuangan.

\section{PENDAHULUAN}

Perkembangan dunia bisnis saat ini menuntut perusahaan untuk memiliki kinerja keuangan yang baik agar lebih mudah menghadapi persaingan bisnis. Kinerja keuangan menyajikan informasi yang diperlukan untuk menilai perubahan potensial sumber daya ekonomi yang saat ini di era revolusi industry 4.0 telah dikendalikan oleh modal intellectual atau Intellectual Capital (IC).

Di Indonesia IC diatur dalam PSAK 19 terbaru (revisi 2010), namun persyaratan dalam aturan tersebut sesungguhnya sulit dipenuhi, sehingga IC belum dapat dilaporkan dalam laporan keuangan perusahaan. Kondisi itu tentu menyulitkan bagi calon investor untuk melakukan analisis dan penilaian atas prospek perusahaan di masa yang akan datang berdasarkan potensi IC yang dimiliki. Calon investor menilai IC memiliki potensi untuk mendukung kinerja keuangan perusahaan menjadi lebih baik sehingga akan berdampak bagi pada prospek perusahaan ke depanya. Sejumlah penelitian telah dilakukan untuk meneliti hubungan IC terhadap kinerja keuangan. Chen et al.,(2005), Tan et al.,(2007), Soetedjo dan Mursida (2008), Ullum et al.,(2008), Gamayuni (2010), Fajarini dan Firmansyah (2012), Yunita (2012), Kumalasari (2013), Prastya (2014) dalam penelitianya menunjukan adanya pengaruh IC terhadap kinerja keuangan. Hasil yang berbeda disimpulkan oleh Firer dan Williams (2003) serta Subagyo dan Lahagu (2012) yang tidak menemukan adanya pengaruh IC terhadap kinerja keuangan. Pendekatan yang dapat 
digunakan oleh sejumlah penelitian yaitu $\operatorname{VAIC}^{\mathrm{TM}}$ oleh Pulic $(1998,1999,2000)$ dan pendekatan pasar MBIC oleh Edvinson dan Malone (1997).

Eksplorasi determinan kinerja keuangan selanjutnya adalah corporate governance. Good Corporate Governance (CCG) semakin gencar dilakukan semenjak munculnya skandal akuntansi seperti kasus Enron, dan Worldcom yang melibatkan akuntan. Di Indonesia juga telah tercatat beberapa kasus yang melibatkan persoalan laporan keuangan seperti PT. Lippo dan PT. Kimia Farma yang berawal dari terdeteksi adanya manipulasi (Boediono, 2005). Di bidang Pasar Modal saat ini masih terdapat beberapa prinsip yang belum diterapkan pada corporate governance. Dalam rangka mengembangkan penerapan corporate governance yang baik di industri, KNKG mengacu pada prinsip yang diterbitkan oleh Organisation for Economic Co-operation and Development (Bapepam, 2006).

Kinerja keuangan tidak hanya dinilai dari informasi yang sifatnya keuangan, tapi juga dapat melalui informasi non keuangan seperti karakteristik perusahaan yaitu beberapa diantaranya adalah ukuran, umur dan growth opportunity. Hal tersebut menunjukan, informasi yang menyajikan prospek yang baik di masa yang akan datang merupakan signal positif yang akan menarik minat investor untuk berinvestasi, dengan semakin meningkatkatnya investasi otomatis akan berdampak baik bagi kinerja keuangan. Hubungan karakteristik perusahaan dengan kinerja keuangan telah dibuktikan oleh sejumlah penelitian. Hasil penelitian Azhar et al.,(2013), Karyawati et al.,(2013), Izati dan Margaretha (2014) menunjukkan karakteristik perusahaan berpengaruh signifikan terhadap kinerja keuangan. Penelitian ini dimotivasi oleh adanya perbedaaan hasil penelitian terhadap determinan kinerja keuangan yaitu intellectual capital, corporate governance, dan karakteristik menjadi daya tarik tersendiri untuk dilakukan penelitian kembali.

\section{RERANGKA TEORITIS DAN PENGEMBANGAN HIPOTESIS Hubungan Intellectual Capital dengan Kinerja Keuangan}

RBV menjelaskan perusahaan dapat memperoleh keunggulan kompetitif dan kinerja keuangan yang baik dengan cara memanfaatkan aset strategis yang dimiliki sehingga memungkinkan perusahaan untuk mengimplementasikan strategi guna meningkatkan efisiensi dan efektivitas perusahaan (Barney,1991; Wernerfelt, 1984). IC merupakan sumber daya yang mampu menggerakkan kinerja organisasi dan penciptaan nilai (Bontis, 1998). Perusahaan yang tidak yakin terhadap potensi IC dan tidak serius untuk mengelola dan mengembangkanya tidak akan berpengaruh terhadap kinerja keuangan. Penelitian Williams (2003) serta Subagyo dan Lahagu (2012) tidak menemukan adanya pengaruh IC terhadap kinerja keuangan. Hasil penelitian yang berbeda ditunjukkan oleh Tan et al.,(2007), Chen et al.,(2005), Ullum et al.,(2008), Soetedjo dan Mursida (2008), Gamayuni (2010), Fajarini dan Firmansyah (2012), Yunita (2012), Kumalasari (2013), Prastya (2014), yang menunjukan adanya pengaruh IC terhadap kinerja keungan. Perusahaan yang yakin terhadap potensi IC akan memaksimalkan perhatian dan pengelolan IC sehingga akan menghasilkan kinerja keuangan yang semakin optimal. Berdasarkan uraian diatas, maka hipotesis pertama adalah sebagai berikut :

\section{$\mathrm{H}_{1}$ : Intellectual Capital berpengaruh positif terhadap kinerja keuangan.}

\section{Hubungan Corporate Governance Dengan Kinerja Keuangan}

Agency theory menjelaskan adanya hubungan kontrak antara agent dan principal yang dimana agent menerima mandat untuk mengelola perusahaan dari principal, yang memungkinkan terjadinya benturan kepentingan keduanya (Jensen dan Meckling, 1976). Hal tersebut akan berakibat pada berkurangya kepercayaan investor yang berimbas pada menurunya jumlah investasi yang diperoleh perusahaan. Sistem corporate governance yang baik mampu mengatasi dan memberikan perlindungan efektif kepada para pemegang saham dan pihak kreditur dari kemungkinan adanya benturan 
kepentingan, sehingga bisa meyakinkan investor untuk memperoleh kembali investasinya dengan wajar dan bernilai tinggi (Susilawati dan Soetjipta, 2013).

Saat ini sejumlah perusahaan di pasar modal masih belum secara penuh menerapkan praktik corporate gvernance yang merujuk pada prinsip GCG, sehingga corporate governance tidak dapat berperan efektif bagi kinerja keuangan perusahaan. Sesuai dengan penelitiaan Arifani (2013), Windah dan Andono (2013) dan Supatmi (2007) yang menunjukan corporate governance tidak berpengaruh terhadap kinerja keuangan. Corporate governance dapat berperan efektif pada perusahaan apabila memenuhi standar praktik corporate governance yang merujuk pada prinsip-prinsip GCG seperti prinsip OECD (2004) yaitu memuat mengenai hak pemegang saham, kesetaraan perlakuan terhadap pemegang saham, peran pemangku kepentingan, pengungkapan dan transparansi, serta pertanggungjawaban dewan (Handajani et al., 2014). Dengan semakin efektifnya peran corporate governance akan meningkatkan kepercayaan dan jumlah investasi yang diperoleh dari investor sehingga perusahaan dapat menghasilkan kinerja keuangan yang optimal. Corporate governance berpengaruh terhadap kinerja keuangan dibuktikan oleh penelitian Kllaper dan Love (2002), Cornet et al.,(2005), Supatmi (2007), Arifani (2013), Windah dan Andono (2013), Utari dan Fachrurzzaman (2013), Prastya (2014). Berdasarkan uraian diatas, maka hipotesis kedua dalam penelitian ini adalah sebagai berikut :

\section{$\mathrm{H}_{2}$ : Corporate Governance Berpengaruh Positif Terhadap Kinerja Keuangan Perusahaan.}

\section{Hubungan Karakteristik Perusahaan Dengan Kinerja Keuangan}

Faktor yang mempengaruhi kinerja keuangan yang telah diuji oleh sejumlah penelitian adalah karakteristik perusahaan. Hubungan karakteristik perusahaan dengan kinerja keuangan berlandaskan pada signalling theory oleh Sharpe (1997:211). Signalling teory menjelaskan pengumuman informasi akuntansi seperti karakteristik perusahaan(ukuran, umur dan growth opportunity) yang memberikan signal positif akan menunjukan bahwa perusahaan mempunyai prospek yang baik di masa mendatang (good news) sehingga menarik minat investor untuk berinvestasi, dengan semakin meningkatkan investasi otomatis akan semakin meningkatknya kinerja keuangan. Hasil penelitian Azhar et al.,(2013), Karyawati et al.,(2013), Izati dan Margaretha (2014) menunjukkan karakteristik perusahaan berpengaruh signifikan terhadap kinerja keuangan. Berdasarkan uraian diatas maka hipotesis ketiga dalam penelitian ini adalah sebagai berikut :

\section{$\mathrm{H}_{3}$ : Karakteristik Perusahaan Berpengaruh Positif terhadap Kinerja Keuangan.}

\section{METODE PENELITIAN}

\section{Populasi data Penelitian}

Perusahan manufaktur yang terdaftar di Bursa Efek Indonesia periode 2016-2018. dengan menggunakan metode purposive sampling berjumlah 38 perusahaan sebagai sampel.

\section{Variabel Penelitan dan Pengukuran}

\section{1). Kinerja Keuangan}

Kinerja keuangan adalah ukuran prestasi yang dapat dicapai oleh perusahaan yang mencerminkan kondisi kesehatan keuangan dari suatu perusahaan dalam periode tertentu. (Munawir, 2002:24).
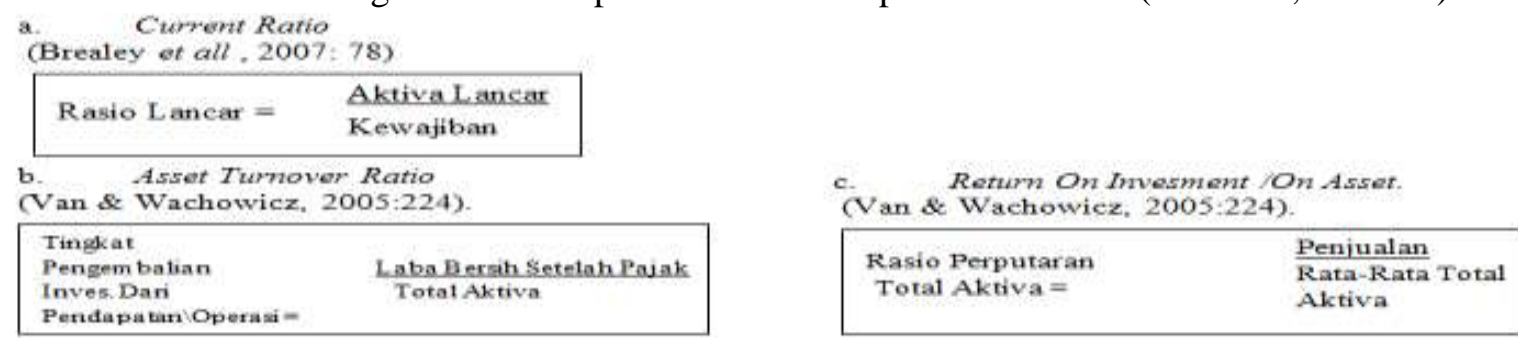


\section{2). Intellectual Capital}

IC merupakan sumber daya, kemampuan dan kompetensi, yang menggerakkan kinerja organisasi dan penciptaan nilai (Bontis, 1998:67). IC dalam penelitian ini diukur menggunakan metode VAIC ${ }^{\mathrm{TM}}$ dan MBIC :

\begin{tabular}{|l|l|}
\hline \multicolumn{1}{|c|}{ Rasio } & \multicolumn{1}{c|}{ Keterangan } \\
\hline Tahap 1: BVNA =BVOA-BVOL & BVNA :book value net asset. \\
Tahap 2: CMV = outstanding share $x$ harga saha & BVOL :book value of liabilities. \\
Tahap 3: & BVOA :book value of asset \\
MBIC $=\log$ natural CMV-log natural BVNA & CMV :corporate market value. \\
& MBIC :market based intellectual \\
& capital.
\end{tabular}

\section{3). Corporate Governance}

Corporate governance merupakan sistem yang mengendalikan perusahaan dengan mengatur hubungan hak dan kewajiban antara stakeholder dan shareholder (Tjager dkk., 2003:25). Penilaian praktik corporate governance menurut OECD (2004) memuat mengenai hak pemegang saham, kesetaraan perlakuan terhadap pemegang saham, peran pemangku kepentingan, pengungkapan dan transparansi, serta pertanggungjawaban dewan.

\begin{tabular}{|c|c|}
\hline Fasióa & Keterangan \\
\hline $\begin{array}{l}\text { Tahap 1: } \\
\text { VA-OUT-IN } \\
\text { Tahap 2: VACA-VA/CE } \\
\text { Tahap 3: VAHU-VA/HC } \\
\text { Tahap 4: STVA-SC/VA } \\
\text { Tahaps: } \\
\text { VAICTA- VACA+VAHU+ STVA }\end{array}$ & 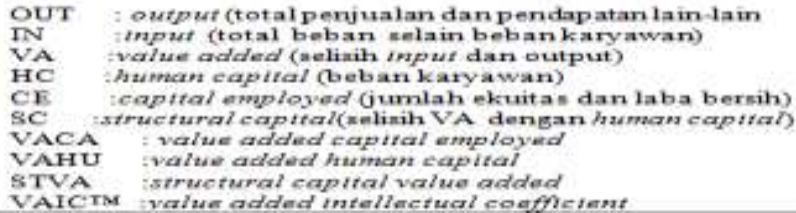 \\
\hline
\end{tabular}

\section{4). Karakteristik Perusahaan.}

Karakteristik perusahaan adalah cerminan dari kondisi fundamental perusahaan yang sebenarnya (Karyawati et al.,2013).

a. Ukuran Perusahaan

Size $=\log$ natural dari total sales

b. Growth oppurtinity

Pertumbuhan $=\frac{\text { Total Aset }}{\text { T }_{\mathrm{t}}-\text { Total Aset }_{\mathrm{t}-\mathrm{I}}}$

\section{5). Analisis dan Data}

Penelitian ini melibatkan tiga variabel eksogen (intellectual capital, corporate governance, karakteristik perusahaan) dan satu variabel endogen (kinerja keuangan).

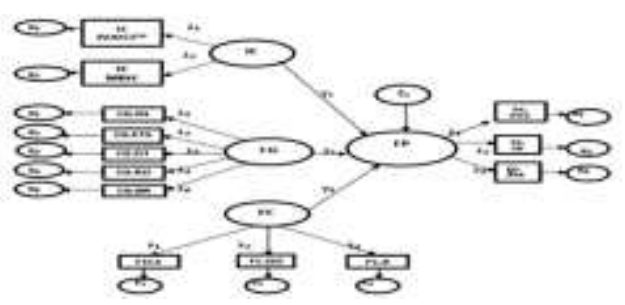

Gambar 3.1. Model Pengukuran dan Struktural 
Model diuji dengan persamaan sebagai berikut :

$$
\begin{aligned}
& \mathrm{IC}=\lambda_{1} \mathrm{VAIC}^{\mathrm{TM}}+\lambda_{2} \mathrm{MBIC}+\varepsilon_{\mathrm{i}} \\
& \mathrm{CG}=\lambda_{1} \mathrm{RS}+\lambda_{2} \mathrm{ET}+\lambda_{3} \mathrm{RO}+\lambda_{4} \mathrm{DT}+\lambda_{5} \mathrm{BR}+\varepsilon_{\mathrm{i}} \\
& \mathrm{FC}=\lambda_{1} \mathrm{~S}+\lambda_{2} \mathrm{GO}+\lambda_{3} \mathrm{~A}+\varepsilon_{\mathrm{i}}
\end{aligned}
$$

Model persamaan struktural diuji dengan persamaan sebagai berikut :

Keterangan :

$$
\mathrm{FP}=\gamma_{1} \mathrm{ROA}+\gamma_{2} \mathrm{CR}+\gamma_{3} \mathrm{ATR}+\zeta_{1}
$$

$\lambda=$ Lamda, Matrik loading indikator reflektif, $\varepsilon=$ Epsilon, galat pengukuran indikator reflektif, $\gamma=$ Gamma, koefisien pengaruh variabel eksogen, $\zeta$ =Zeta, galat model

Intellectual Capital(IC), direfleksikan dengan indikator :

IC. VAIC $^{\mathrm{TM}}=$ Vaule Added Intellectual Coefficient, IC. MBIC =Intellectual Capital Market Based

Corporate Governance $(C G)$, direfleksikan dengan indikator

CG.RS $=$ Right of Shareholder, CG.ET $=$ Equitable Treatment of Shareholder; CG.RO $=$ Role of Stakeholder in Corporate Governance, CG.DT $=$ Disclosure and Transparency, $\mathrm{CG} . \mathrm{BR}=$ Board Responsibility

Firm Characteristic (FI) direflekasikan dengan indikator:

FC.S $=$ size, FC.GO=Growth Opportunity, FC. A = Age

\section{HASIL DAN PEMBAHASAN}

\section{Hasil Pengujian Model Pengukuran, Model Struktural, Goodness of fit}

Hasil pengujian hipotesis dalam penelitian ini telah memenuhi asumsi uji linieritas dengan aplikasi SPSS 21 dengan model curve estimation. Indikator yang merefleksikan konstruk berdasarkan hasil kalkulasi awal algoritma PLS menunjukkan indikator current ratio dan growth opportunity harus di drop dari model karena nilai loading faktornya $<0,5$. Selanjutnya di lakukan proses calculate algorithm kembali dan diperoleh hasil kalkulasi akhir algoritma seperti gambar di bawah ini:

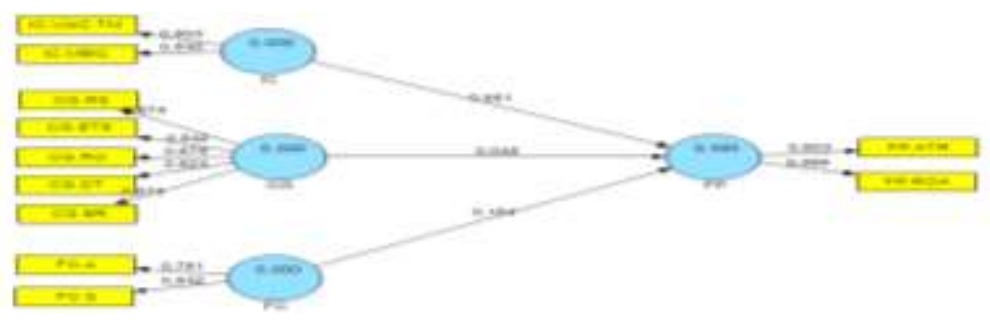

Gambar 4.1. Hasil Kalkulasi Akhir Algoritma PLS

Berdasarkan gambar 4.1. dapat dilihat loading factor untuk keseluruhan indikator $>0,5$, sehingga telah memenuhi uji convergen validity. Variabel FP, IC, CG, dan FC memiliki composite reliability > 0,7, artinya ke empat variabel tersebut variabel. Selain uji convergent validity, konstruk dengan indikator reflektif juga perlu diuji reliabilitas model dengan melihat composite reliability pada output algoritma PLS, seperti pada tabel 4.4 berikut ini :

Tabel 4.4 Composite Reliability

\begin{tabular}{cc}
\hline & $\begin{array}{c}\text { Composite } \\
\text { Reliability }\end{array}$ \\
\hline FP & 0,770824 \\
IC & 0,800368 \\
CG & 0,887643 \\
FC & 0,771113 \\
\hline
\end{tabular}

Sumber: Lampiran 9 
Selanjutnya konstruk dengan indikator reflektif diuji validitasnya model dengan melihat Tstatistik pada outer loadings seperti pada tabel 4.5 berikut :

Tabel 4.5

Outer loadings (Mean, STDEV, T-Values)

\begin{tabular}{|c|c|c|c|c|c|c|}
\hline & $\begin{array}{c}\text { Original } \\
\text { Saraple (O) }\end{array}$ & $\begin{array}{l}\text { Sample } \\
\text { Mesa (M) }\end{array}$ & $\begin{array}{l}\text { Standard } \\
\text { Deviatien } \\
\text { STDEV }\end{array}$ & $\begin{array}{l}\text { Standard } \\
\text { Error } \\
\text { (stracs) }\end{array}$ & $\begin{array}{l}\text { T Statiaties } \\
\text { gOrstrkek0 }\end{array}$ & Keterangan \\
\hline$C O A R<C G$ & 0.572968 & 0.869057 & 0.027308 & $0.02130 \mathrm{~s}$ & 31,734966 & Sienditian \\
\hline $\mathrm{CODT}<\mathrm{CQ}$ & 0.623351 & 0.61933 & 0.071477 & 0.97477 & 7943024 & tiendikan \\
\hline coxTs< co & Q.541959 & 0,534536 & 0.049122 & 0.049182 & 17,119421 & Siendikar \\
\hline $\operatorname{cox} 0<c \theta$ & 0,678528 & 0.674527 & 0,07833 & 0,07153 & 8.662424 & Syeritikar \\
\hline coes $<$ co & 0.573995 & 0,866645 & 0,042199 & 0.042199 & 20,711512 & Sienditian \\
\hline$F C A<B C$ & 0,751409 & 0,753696 & 0.066791 & 0.036791 & 8.657697 & Sigenditian \\
\hline $\mathrm{FC} s<\mathrm{FC}$ & 0,831601 & 0,822135 & 0,073136 & 0,073186 & 11362785 & Signdikan \\
\hline WATR< & 0,602248 & 0,541268 & 0,160478 & $0,16047 \mathrm{a}$ & 3,75659 & Signtitian \\
\hline FHOA $<$ F & 0.956051 & 0.935442 & 0,019723 & 0.019723 & 48,4602112 & Sientitan \\
\hline IC MRBIC $<$ ic & 0,830287 & 0,129302 & 0.035462 & 0.035462 & 23.413548 & Sigrdikan \\
\hline IC VAIC $\mathrm{IM}<$ IC & 0,503112 & 0,501067 & 0,05413 & 0,05413 & 14,838076 & Sigudian \\
\hline
\end{tabular}

Sumber : output bootsrapping smart pls (2015)

Berdasarkan tabel 4.5 diatas, dapat dilihat outer loadings untuk empat variabel dengan indiaktor reflektif sebagai berikut :

1) Kelima indikator variabel CG yaitu CG.BR $=0,872968$, CG.DT $=0,623351$, CG.ETS $=0,841959$, CG.RO=0,678528, CG.RS=0,873995 mampu merefleksikan variabel corporate governnace. Dapat disimpulkan bahwa indikator tanggung jawab dewan (CG.BR=0,872968), hak pemegang saham (CG.ETS $=0,841959)$ dan kesetaraan perlakuan terhadap pemegang saham (CG.RS= 0,873995) dominan dalam merefleksikan corporate governance. Artinya, perusahaan harus mengedepankan tiga prinsip OECD (2004) yang memuat mengenai tanggung jawab dewan, hak pemegang saham, dan kesetaraan perlakuan terhadap pemegang saham karena tiga prinsip tersebut berkaitan langsung dengan perlindungan yang efektif bagi investor. Dilihat dari nilai $\mathrm{T}$ statistik dapat disimpulkan keseluruhan indikator signifikan dalam merefleksikan variabel corporate governance karena nilai $\mathrm{T}$ statistik > 1,64.

2) Kedua indikator variabel FC yaitu FC.A $=0,751409$ dan FC.S $=0,831601$ mampu merefleksikan karakteristik perusahaan. Dapat disimpulkan bahwa indikator ukuran perusahaan (FC.S=0,831601) dominan dalam merefleksikan karakterisitik perusahaan. Artinya perusahaan yang mampu mengoptimalkan penjualanya sebagai tolak ukuran besarnya perusahaan, menunjukan keberhasilan perusahaan dalam mencapai target yang ingin dicapai perusahaan dan yang diharapakan oleh investor. Dilihat dari nilai $\mathrm{T}$ statistik dapat disimpulkan keseluruhan indikator signifikan dalam merefleksikan variabel karakteristik perusahaan karena nilai T statistik . 1,64.

3) Kedua indikator variabel FP yaitu FP.ROA= 0,956058 dan FP.ATR= 0,602848 mampu merefleksikan kinerja keuangan. Dapat disimpulkan bahwa indikator profitabilitas perusahaan (FP.ROA=0,956058) dominan dalam merefleksikan kinerja keuangan. Artinya, perusahaan harus mengedepankan dan meningkatkan profitabilitas atau laba yang dimiliki perusahaan karena hal tersebut merupakan daya menarik minat investor untuk berinvestasi. Dilihat dari nilai T statistik dapat disimpulkan keseluruhan indikator signifikan dalam merefleksikan variabel kinerja keuangan perusahaan karena nilai $\mathrm{T}$ statistik $.1,64$.

4) Kedua indikator variabel IC yaitu IC.VAIC ${ }^{\mathrm{TM}}=0,803182$ dan IC.MBIC $=0,830287$ mampu merefleksikan intellectual capital. Dapat disimpulkan bahwa walaupun nilainya tidak beda jauh antara indikator market based yang mengukur intangible assset $(\mathrm{IC} . \mathrm{MBIC}=0,830287)$ dengan $\mathrm{IC} . \mathrm{VAIC}{ }^{\mathrm{TM}}=$ 0,803182, namun intangible asset lebih dominan dalam merefleksikan intellectual capital. Artinya, perusahan lebih menunjukan intellectual capital dalam bentuk intangible asset dengan pendekatan 
pasar dikarenakan persyaratan pelaporan IC berdasarkan PSAK 19 revisi (2010) mengenai potensi IC yang dimiliki perusahaan masih sulit untuk dipenuhi perusahaan.

Berdasarkan perhitungan R-square hasil kalkulasi algoritma PLS diperoleh hasil sebagai berikut :

Tabel 4.1. $R$ Square

\begin{tabular}{lc}
\hline & $R$ Square \\
\hline CG & \\
FC & \\
FP & 0,594960 \\
IC & \\
\hline
\end{tabular}

Berdasarkan tabel 4.1, dapat disimpulkan bahwa variabel financial perfomance (FP) dapat dijelaskan oleh variabel IC, CG dan FC sebesar 0,594960 atau 59,46 \% sementara 40,54 \% diterangkan oleh variabel lain yang tidak diteliti. Konstruk variabel financial perfomance (FP) dapat diterangkan oleh konstruk variabel intellectual capital (IC), corporate governance (CG) dan firm characteristic (FC) sebesar 59,45\%, sehingga masuk dalam kategori moderat karena nilai $\mathrm{r}$ square 0,594960<0,64 dan $>0,33$. Perhitungan godness of fit dalam penelitian ini adalah sebagai berikut :

Tabel 4.2. Godness of fit

\begin{tabular}{cccc}
\hline & R-square & Communality & Gof \\
\hline CG & & 0,616761 & \\
FC & & 0,628088 & \\
FP & 0,594960 & 0,638736 & 0,6 \\
IC & & 0,667239 & \\
\hline & 0,594960 & 0,637706 & \\
\hline
\end{tabular}

Tabel 4.2 menunjukkan index GOF 0,6 yang artinya variansi yang dijelaskan oleh konstruk-konstruk dalam model lebih besar dari faktor residual diluar model. Berdasarkan kriteria index GOF maka model dalam penelitian ini masuk dalam kategori kuat, karena index GOF $>0,36$. Ringkasan hasil pengujian model struktural untuk masing-masing hipotesis dapat dilihat pada tabel dibawah ini :

Tabel 4.3

Path Coefficients (Mean, STDEV, T-Values

\begin{tabular}{cccccc}
\hline & $\begin{array}{c}\text { Original Sample } \\
(\mathbf{O})\end{array}$ & $\begin{array}{c}\text { Sample Mean } \\
(\mathbf{M})\end{array}$ & $\begin{array}{c}\text { T Statistics } \\
(\mid \mathbf{O} / \text { STERR } \mid)\end{array}$ & Hipotesis & Keterangan \\
\hline IC -> FP & 0,68079 & 0,683291 & 14,688620 & $\mathrm{H}_{1}$ & Diterima \\
CG -> FP & 0,048339 & 0,070169 & 0,653099 & $\mathrm{H}_{2}$ & Ditolak \\
FC -> FP & 0,153891 & 0,142485 & 2,053273 & $\mathrm{H}_{3}$ & Diterima \\
\hline
\end{tabular}

Sumber : output bootsrapping smartpls (2015)

1. Variabel IC memiliki koefisien parameter 0,68079 dan nilai t statistik 14,688620 >1,64 (t tabel), artinya IC berpengaruh signifikan positif terhadap kinerja keuangan. Semakin besar IC yang dimiliki oleh perusahaan maka kinerja keuangan akan semakin meningkat. Dengan demikian $\mathrm{H}_{1}$ dalam penelitian ini diterima

2. Variabel CG memiliki koefisien parameter $0,048339<1,64$ ( $\mathrm{t}$ tabel) dan nilai t statistik 0,653099 $<1,64$, artinya $\mathrm{CG}$ tidak berpengaruh signifikan terhadap kinerja keuangan, sehingga $\mathrm{H}_{2}$ dalam penelitian ini ditolak.

3. Variabel FC memiliki koefisien parameter 0,153891 dan nilai t statistik 2,053273 > 1,64 (t tabel), artinya FC berpengaruh signifikan positif terhadap kinerja keuangan. Perusahaan dengan 
karakteristik perusahaan yang bagus akan meningkatkan kinerja keuangan. Dengan demikian $\mathrm{H}_{3}$ dalam penelitian ini diterima.

\section{HASIL PENGUJIAN HIPOTESIS DAN PEMBAHASAN Pengaruh IC terhadap Kinerja Keuangan}

Hasil penelitian ini dapat memberikan bukti bahwa VAIC $^{\mathrm{TM}}$ dan MBIC merupakan indikator yang mampu merefleksikan IC karena nilai t-statistiknya pada outer loadings diatas 1,64. Indikator MBIC lebih dominan dan signifikan dalam merefleksikan IC, walaupun nilainya tidak beda jauh antara indikator market based yang mengukur intangible assset dengan vallue added namun intangible asset lebih dominan dalam merefleksikan intellectual capital. Artinya, perusahan lebih menunjukan intellectual capital dalam bentuk intangible asset dengan pendekatan pasar dikarenakan persyaratan pelaporan IC berdasarkan PSAK 19 revisi (2010) mengenai potensi IC yang dimiliki perusahaan sebagai vallue added perusahaan masih sulit untuk dipenuhi perusahaan.

IC berpengaruh signifikan positif terhadap kinerja keuangan perusahaan manufaktur karena memiliki nilai t-statistik pada path coeficients diatas 1,64 yaitu 14,688620. Hal ini mengindikasikan IC merupakan sumber daya perusahaan yang berhasil menciptakan keunggulan kompetitif melalui VAIC ${ }^{\mathrm{TM}}$ yang menunjang perusahaan untuk beradaptasi pada perubahan-perubahan yang ada di lingkungan bisnis dan berkemampuan untuk meningkatkan laba karena berhasil menampilkan IC sebagai sumber daya yang potensial bagi perusahaan melalui MBIC (market based intellectual capital) sehingga mampu menggerakan kinerja keuangan. Hasil penelitian ini sejalan dengan penelitian Chen et al.,(2005), Tan et al., (2007), Ullum et al.,(2008), Soetedjo dan Mursida (2008), Gamayuni (2010), Yunita (2012), Fajarini dan Firmansyah (2012), Kumalasari (2013), Prastya (2014) yang menyimpulkan adanya pengaruh positif IC terhadap kinerja keuangan. Hal ini mengindikasikan pentinganya pemanfaatan IC dengan semaksimal mungkin oleh perusahaan karena berkaitan dengan usaha perusahan untuk meningkatkan kinerja keuangan.

Hasil penelitian ini tidak sejalan dengan hasil penelitian oleh Firer dan Wiliams (2003) serta Subagyo dan Lahagu (2012) yang tidak menemukan adanya pengaruh IC yang signifikan terhadap kinerja keuangan. Hal ini mengindikasikan kurangnya keyakinan perusahaan terhadap potensi IC sehingga perusahaan tidak sepenuhnya optimal dalam melakukan pengembangan dan pengelolan IC, hal tersebut akan menyebabkan lemahnya kemampuan IC dalam mempengaruhi kinerja keuangan.

IC yang berpengaruh signifikan postif terhadap kinerja keuangan, mengindikasikan perusahaan mampu menghasilkan nilai tambah melalui $\mathrm{VAIC}^{\mathrm{TM}}$ dan meningkatkan nilai intangible asset dengan metode MBIC. VAIC $^{\mathrm{TM}}$ merupakan jumlah dari tiga jenis input perusahaan yaitu modal manusia, modal struktural fisik dan financial yang terdiri dari human capital efficiency, structural capital efficiency dan capital employed efficiency yang dimanfaatkan secara efisien oleh perusahaan sehingga menghasilkan VAIC $^{\mathrm{TM}}$ yang bernilai tinggi. Perusahaan memanfaatkan VAIC ${ }^{\mathrm{TM}}$ untuk menciptakan karakter unik yang dijadikan sebagai keunggulan kompetitif perusahan yang tidak dimiliki perusahaan lain. Pengukuran IC dengan MBIC mengggunakan selisih nilai pasar dengan nilai buku, yaitu dimana semakin besar nilai pasar terhadap nilai buku akan menunjukan tinginya jumlah IC yang dinillai oleh para investor atau shareholder. Tingginya penilaian IC yang diberikan oleh investor mencerminkan keyakinan investor terhadap prospek perusahaan kedepanya yang akan dijadikan bahan pertimbangan dalam keputusan berinvestasi. Dengan demikian pengelolan IC yang optimal dapat dilakukan perusahaan dengan adanya keseriusan perusahaan untuk menghasilkan VAIC $^{\mathrm{TM}}$ yang tinggi dan perhatian terhadap MBIC yang dimiliki karena hal tersebut akan berpengaruh terhadap kinerja keuangan. 


\section{Pengaruh Corporate Governance terhadap Kinerja Keuangan}

Hipotesis ke-2 $\left(\mathrm{H}_{2}\right)$ dalam penelitian ini di tolak dan memberikan bukti bahwa corporate governance tidak mempengaruhi kinerja keuangan perusahaan manufaktur (corporate governance bukan determinan kinerja keuangan). Hasil penelitian memberikan bukti bahwa RS, ETS, RO, DT dan BR merupakan indikator yang mampu merefleksikan CG karena nilai t-statistiknya pada outer loadings diatas 1,64. Indikator tanggung jawab dewan, hak pemegang saham dan kesetaraan perlakuan terhadap pemegang saham lebih dominan dan signifikan dalam merefleksikan corporate governance. Artinya, perusahaan harus mengedepankan tiga prinsip OECD (2004) yang memuat mengenai tanggung jawab dewan, hak pemegang saham, dan kesetaraan perlakuan terhadap pemegang saham karena tiga prinsip tersebut berkaitan langsung dengan perlindungan yang efektif bagi investor. Hal ini mengindikasikan prinsip OECD (2004) yang memuat mengenai hak pemegang saham, keseteraan perlakuan terhadap pemegang saham, peran stakeholder dalam tata kelola perusahaan dan pengungkapan transaparansi telah menjadi kebutuhan bagi perusahaan untuk meciptakan corporate governance yang lebih baik

CG tidak berpengaruh signifikan terhadap kinerja keuangan perusahaan manufaktur karena memiliki nilai t-statistik pada path coefficients dibawah 1,64 yaitu 0,653099. Hasil penelitian ini sejalan dengan penelitian yang dilakukan oleh Supatmi (2007), Windah dan Andono (2013) serta Utari dan Fachurzzman (2013) mengungkapkan bahwa corporate governance tidak berpengaruh terhadap kinerja keuangan. Hal ini mengindikasikan rendahnya tingkat keselarasan antara pelaksanaan praktik corporate governance dengan penilaian akan praktik corporate governance yang baik sehingga belum berhasil meningkatkan kinerja keuangan. Hasil penelitian ini tidak sejalan dengan penelitian Prastya (2014), Klapper dan Love (2002), Cornet et al., (2006), Arifani (2013) yang menemukan adanya pengaruh corporate governance terhadap kinerja keuangan. Hal ini mengindikasikan adanya keselarasan yang baik antara pelaksanaan dan indikator yang digunakan dalam mengukur praktik corporate governance yang baik. Tingkat keselaran yang tinggi mendukung kekuatan praktik corporate governance dalam untuk berhasil meningkatkan kinerja keuangan.

Corporate governance yang tidak berpengaruh signifikan terhadap kinerja keuangan, mengindikasikan praktik corporate governance yang merujuk pada prinsip OECD (2004) masih di dominasi pada prinsip yang sudah menjadi ketentuan yang ditetapkan oleh Bapepam yaitu keterbukaan dan transparansi serta tanggung jawab dewan. Dari tiga prinip yang belum ditetapkan Bapepam hanya peran stakeholder dalam corporate governance yang mampu menyimbangi dua prinsip yang mendominasi tersebut, sedangakan dua prinsip OECD (2004) yaitu hak pemegang sahan dan kesetaraan terhadap perlakuan terhadap pemegang saham masih rendah.

\section{Pengaruh Karakteristik perusahaan pada Kinerja keuangan}

Hipotesis ke-3 dalam penelitian ini diterima dan memberikan bukti bahwa karakteristik perusahaan dapat mempengaruhi kinerja keuangan (karakteristik perusahaan merupakan determinan kinerja keuangan). Hal ini mengindikasikan karakteristik perusahaan yang mencerminkan kondisi fundamental perusahaan yang baik dapat meningkatkan kinerja keuangan.

Hasil penelitian ini dapat memberikan bukti bahwa ukuran dan umur perusahaan merupakan indikator yang mampu dalam merefleksikan karakteristik perusahaan karena memiliki nilai t-statistik pada outer loadings diatas 1,64. ukuran perusahaan $(\mathrm{FC} . \mathrm{S}=0,831601)$ lebih dominan dan signifikan dalam merefleksikan karakterisitik perusahaan. Artinya perusahaan yang mampu mengoptimalkan penjualanya sebagai tolak ukuran besarnya perusahaan, menunjukan keberhasilan perusahaan dalam mencapai target yang ingin dicapai perusahaan dan yang diharapakan oleh investor.

Karakteristik perusahaan (FC) berpengaruh signifikan positif terhadap kinerja keuangan perusahaan manufaktur karena memiliki nilai t-statistik pada path coefficients diatas 1,64 yaitu 2,053273. 
Hal ini mengindikasikan peningkatan jumlah investasi yang akan meningkatkan kinerja keuangan dipengaruhi oleh tampilan dari karakteristik perusahaan melalui ukuran dan umur perusahaan Perusahaan besar memiliki kecenderungan melakukan diversifikasi dan kemungkinan untuk mengalami kebangkrutan semakin kecil dan dapat memanfaatkan ukuran yang besar tersebut untuk mendapatkan kesepakatan yang lebih baik di bidang keuangan (Izati dan Margaretha, 2014). Sedangkan Umur perusahaan menunjukkan kemampuan suatu perusahaan dalam kualitas eksistensinya dan kemampuan perusahaan untuk bersaing dan mampu untuk bertahan dalam persaingan (Azhar et al.,2009).

Hasil penelitian ini sejalan dengan penelitian yang dilakukan Karyawati et al., (2013) dan Azhar et al.,(2013) dan Izati dan Margaretha (2014) yang mengungkapkan adanya pengaruh yang signifikan terhadap kinerja keuangan. Hal ini mengindikasikan karakteristik perusahaan yang ditampilkan perusahan dalam laporan tahunan akan menentukan keyakinan investor untuk berinvestasi sehingga berpengaruh terhadap keberhasilan perusahan dalam meningkatkan kinerja keuangan.

Karakteristik perusahaan berpengaruh signifikan terhadap kinerja keuangan, mengindikasikan karakteristik perusahaan yaitu ukuran dan umur perusahaan Semakin besar ukuran dan semakin tua umur perusahaan dapat menciptakan karakteristik perusahaan yang baik sehingga mampu menarik investor untuk meningkatkan jumlah investasinya yang menunjang keberhasilan perusahaan dalam meningkatkan kinerja keuangan.

\section{SIMPULAN DAN KETERBATASAN Simpulan}

Hasil penelitan ini menunjukkan bahwa IC berpengaruh signifikan postif terhadap kinerja keuangan yang mengindikasikan semakin tinggi IC perusahaan maka kinerja keuangan akan semakin tinggi. Perusahaan dengan IC yang tinggi didukung dengan adanya keseriusan perusahaan untuk menghasilkan nilai tambah dengan metode $\mathrm{VAIC}^{\mathrm{TM}}$ yang tinggi dan menaikan nilai intangible asset dengan metode MBIC. Karakteristik perusahaan berpengaruh signifikan positif terhadap kinerja keuangan, yang mengindikasikan semakin baik karakteristik perusahaan maka kinerja keuangan akan semakin meningkat. Karakteristik perusahaan yang baik dicerminkan dengan besarnya ukuran dan umur perusahaan karena menunjukan adanya produktifitas perusahaan yang bagus dan adanya pengalaman manajemen untuk menghasilkan profitabilitas yang stabil. Corporate governance tidak berpengaruh signifikan terhadap kinerja keuangan yang mengindikasikan rendahnya tingkat keselarasan pelaksanaan praktik corporate governance terhadap keseluruhan prinsip OECD (2004). Pelaksanaan prinsip OECD (2004) masih di dominasi oleh peran stakeholder dalam corporate governance, keterbukaan dan transparansi serta tanggungjawab dewan. Kedepanya perusahaan harus lebih meningkatkan perhatian dan kepatuhan terhadap prinsip hak pemegang saham dan kesetaraan perlakukan terhadap pemegang saham.

\section{Keterbatasan dan Saran Penelitian Mendatang.}

Pertama, penelitian ini hanya menggunakan data 3 tahun dan subjek hanya pada perusahaan manufaktur. Agar menghasilkan hasil penelitian yang optimal, penelitian selanjutnya dapat menggunakan data penelitian lebih dari 3 tahun dan menambah subjek penelitian selain pada perusahaan manufaktur seperti pada perusahaan perbankan. Subjek penelitian yang berbeda tentunya memiliki perbedaaan pada karakter IC, kepatuhan pada keseluruhan prinsip OECD (2004) dan karakteristik perusahaan. Kedua, IC dalam penelitian ini hanya menggunakan 2 indikator yaitu metode VAIC $^{\mathrm{TM}}$ dan MBIC. Penelitian selanjutnya dapat menambahkan indikator lain seperti model The EVA dan MVA oleh Bontis et. al, (1999). Ketiga, penelitian selanjutnya dapat menggunakan indikator prinsip OECD (2008) yang diutamakan bagi perusahaan multinasional. 
Referensi :

Arifani, Rizky. 2012. Pengaruh Good Corporate Governance Terhadap Kinerja Keuangan Perusahaan. Universitas Brawijaya.

Azhar, Kirmizi dan Diajeng Eka Putri.2013. Analisis Karakteristik Perusahaan yang Mempengaruhi Kinerja Keuangan Perusahaan. Fakultas Ekonomi Universitas Riau.

Badan Pengawasan Pasar Modal Dan Lembaga Keuangan (Bapepam).2006. Studi Penerapan Prinsipprinsip OECD 2004 dalam Peraturan Bapepam mengenai Corporate Governance.

Boediono, Gideon Setyo Budiwitjaksono. 2005. Kualitas Laba: Studi Pengaruh Mekanisme Corporate Governance dan Dampak Manajemen Laba Dengan Menggunakan Analisis Jalur. Simposium Nasional Akuntansi VIII. Solo.

Chen, M.C., S.J. Cheng, Y. Hwang. 2005. "An Empirical Investigation of the Relationship between Intellectual Capital and Firms' Market Value and Financial Performance”. Journal of Intellectual Capital. Vol. 6 N0. 2. pp. 159-176.

Fajarini, Indah dan Riza Firmansyah. 2012. Pengaruh Intellectual Capital Terhadap Kinerja Keuangan (Studi Empiris Perusahaan LQ 45). Jurnal Dinamikan Akuntansi.

Gamayuni, Rindu Rika. 2010. Pengaruh Intangible Asset, Kebijakan Keuangan, dan Kinerja Keuangan Terhadap Nilai Perusahaan. Universitas Lampung.

Izati, Chaerunisa dan Farah Margaretha. 2014. Faktor- faktor Yang Mempengaruhi Kinerja Keuangan Pada Perusahaan Basic Industry and Chemicals Di Indonesia. Universitas Tri Sakti.

Jensen, M., and W. Meckling 1976. Theory of the Firm : Managerial Behavior, Agency, and Ownership Structure. Journal of Financial Economics,(1976), 305-360.

Karyawatiet al.2013. Pengaruh Karakteristik Perusahaan, Faktor Eksternal dan Struktur Modal terhadap Kinerja Keuangan Perusahaan. Universitas Brawijaya Malang.

Klapper, Leora F. and I. Love. 2002. Corporate Governance, Investor Protection, and Performance in Emerging Markets. World Bank Working Paper. http:// ssrn.com.

Kumalasari dan Astika.2013. Pengaruh Modal Intellektual terhadap Kinerja Keuangan di Bursa Efek Indonesia. Fakultas Ekonomi Universitas Udayana Bali.

Nakamura, L. 1999. "Intangibles: What Put the New in The New Economy?. Federal Reserve Bank of Philadelphia Business Review. (July/August): 16. Organisation for Economic Cooperation and Development (OECD). 2004. Principles of Corporate Governance 2004.

Prastya, Ony Maretha. 2014. Pengaruh Modal Intellektual dan Tata Kelola Perusahaan terhadap Kinerja Keuangan. Universitas Negeri Surabaya.

Pulic, A. 1998. Measuring the Performance of Intellectual Potential in Knowledge Economy. Available from: www.vaic-on.net.

Soetedjo dan Mursida.2008.Pengaruh Intellectual Capital terhadap Kinerja Keuangan Pad Perusahaan Perbankan. Fakultas Ekonomi dan Bisnis Universitas Airlangga Surabaya.

Song, H.S. (2005). Capital Structure Determinants: An Empirical Study of Swedish Companies. Presented at Conference "Innovation Entrepreneurship and Growth".

Supatmi.2007. Corporate Governance dan Kinerja Keuangan. Fakultas Ekonomi Universitas Kristen Satya Kencana.

Ullum et al. 2008.Intellectual Capital dan Kinerja Keuangan Perusahaan: Suatu Analisis dengan Pendekatan Partial Least Squares. SNA XI Pontianak.

Utari, Ayu Dwi dan Fachruzzaman.2013. Analisis Pengaruh Mekanisme Corporate Governance, Firm Size, dan Growth Oppurtunity Terhadap Kinerja Perusahaan BUMN Yang Terdaftar Di BEI Periode 2007-2012. Universitas Bina Nusantara.

Van Horne, James C. And John. M Wachowicz.2005. Prinsip-prinsip Manajemen Keuangan Buku Satu. Edisi Kedua Belas. Jakarta Salemba Empat.

Wernerfelt, B. 1984. A Resourced-Based View of The Firm. Strategic Management Journal. Vol.5: 171-180.

Windah, Gabriela Cynthia dan Fidelis Arastyo Andono. 2013. Pengaruh Penerapan Corporate Governance Terhadap Kinerja Keuangan. Universitas Surabaya.

Yunita, Novelina.2013. Pengaruh Modal Intellektual terhadap Kinerja Keuangan dan Nilai Pasar. Jurusan Akuntansi, Fakultas Ekonomi, Universitas Negeri Semarang. 